\title{
PENGARUH IMPLEMENTASI UU NO.22 TAHUN 2009 TENTANG LALU LINTAS ANGKUTAN JALAN (LLAJ) TERHADAP DISIPLIN PENGEMUDI ANGKUTAN KOTA DI KOTA BOGOR
}

\section{THE EFFECT OF IMPLEMENTATION OF LAW NO.22 OF 2009 ON ROAD TRAFFIC AND TRANSPORT (LLAJ) ON THE DISCIPLINE OF PUBLIC TRANSPORTATION DRIVERS IN THE CITY OF BOGOR}

\author{
Ijang Bunyamin 1 , Euis Salbiah², G. Goris Seran ${ }^{3}$ \\ 1Jurusan Ilmu Administrasi Negara Fakultas Ilmu Sosial dan Ilmu Politik Universitas \\ Djuanda, Jl. Tol Ciawi No. 1, Kotak Pos 35 Bogor 16770. \\ 2Jurusan Ilmu Administrasi Negara Fakultas Ilmu Sosial dan Ilmu Politik Universitas \\ Djuanda, Jl. Tol Ciawi No. 1, Kotak Pos 35 Bogor 16770. \\ ${ }^{3}$ Jurusan Ilmu Administrasi Negara Fakultas Ilmu Sosial dan Ilmu Politik Universitas \\ Djuanda, Jl. Tol Ciawi No. 1, Kotak Pos 35 Bogor 16770. \\ aKorespondensi: Ijang Bunyamin.
}

(Diterima oleh Dewan Redaksi: 01-08-2015)

(Dipublikasikan oleh Dewan Redaksi: 01-10-2015 )

\begin{abstract}
The objective of this research is to know the influence of implementation of Law No.22 of 2009 in its influence on the discipline of public transportation drivers in the city of Bogor, how a causal effect on the implementation of Law No. 22 of 2009 on the LLAJ.

The method used in this research is associative. The research aims to determine the relationship between two or more variables. With this research it will be constructed a theory that could serve to explain, predict, and control a symptom. For data analysis used the formula Weight Mean Score (WMS). Population employee who becomes the object of observation of 70 people and the population of the city transport driver and the driver as much as 3412 to determine the sample size used Yamane formula so that the number of samples used to 41 employees and 97 DLLAJ transport drivers in the city of Bogor. To search for correlation using Spearman Rank Correlation formulas with the help of calculations using SPSS software version 20.0.

The results showed Effect of Implementation of Law No. 22 of 2009 on the Discipline of public transportation drivers in the city of Bogor was pretty good. It can be seen that the significance of 0.000 is less than 0.05 , the null hypothesis is rejected, the conclusion that there is a close and meaningful relationship between the application of Law No. 22 of 2009 Implementation of the Work Discipline driver of public transportation in the city of Bogor. Of the output data obtained Spearman's rho correlation coefficient of 0.919 . Because the value is closer to 1 , the relationship between the implementation of the Work Discipline is strong. Rank too high a value on the positive and that is equal to 0.680. The value of the coefficient is positive $(+)$, meaning that if higher then Item Implementation Work Discipline will increase if Item Implementation of high or low it will affect the Work Discipline low as well. The relationship between the implementation of the Work Discipline significant influence (strong).
\end{abstract}

Keywords: Implementation, Discipline, Public Transportation, Transportation Management 


\begin{abstract}
ABSTRAK
Tujuan dari Penelitian ini untuk mengetahui sejauh mana Implementasi UU No.22 Tahun 2009 dalam pengaruhnya terhadap disiplin pengemudi angkutan kota di Kota Bogor, bagaimana efek sebab akibat atas pelaksanaan UU No.22 Tahun 2009 tentang LLAJ tersebut.

Metode yang digunakan dalam penelitian ini adalah penelitian asosiatif, yaitu penelitian yang bertujuan untuk mengetahui hubungan antara dua variabel atau lebih. Dengan penelitian ini maka akan dapat dibangun suatu teori yang dapat berfungsi untuk menjelaskan, meramalkan, dan mengontrol suatu gejala. Untuk analisis data digunakan rumus Weight Mean Score (WMS). Populasi pegawai yang menjadi objek pengamatan sebanyak 70 orang serta populasi sopir angkutan kota sebanyak 3412 pengemudi dan untuk menentukan besaran sampel dipergunakan rumus Yamane sehingga jumlah sampel yang digunakan menjadi 41 orang pegawai DLLAJ dan 97 orang sopir angkutan kota di Kota Bogor. Untuk mencari hubungan korelasi menggunakan rumus Korelasi Rank Spearman dengan bantuan perhitungan menggunakan software SPSS versi 20.0.

Hasil penelitian ini menunjukkan Pengaruh Implementasi UU No.22 Tahun 2009 Terhadap Disiplin Pengemudi Angkutan Kota di Kota Bogor adalah cukup baik. Dapat diketahui bahwa signifikansi sebesar 0,000 kurang dari 0,05 maka hipotesis nol ditolak, kesimpulannya yaitu ada hubungan yang erat dan berarti antara penerapan Implementasi UU No.22 tahun 2009 terhadap Disiplin Kerja Sopir Angkot di Kota Bogor. Dari data output didapat koefisien korelasi Spearman's rho sebesar 0,919. Karena nilai lebih mendekati 1 maka hubungan antara Implementasi dengan Disiplin Kerja adalah kuat. Nilai pada Rank pun tinggi dan positif yaitu sebesar 0,680. Nilai koefisien bertanda positif (+), artinya jika Item Implementasi tinggi maka Item Disiplin Kerja akan mengalami peningkatan tinggi atau jika Item Implementasi rendah maka akan berpengaruh pada Disiplin Kerja yang rendah juga. Hubungan antara Implementasi dengan Disiplin Kerja berpengaruh secara signifikan (kuat).

Kata Kunci: Implementasi, Disiplin, Angkutan Kota, Manajemen Transportasi
\end{abstract}

Ijang, 2015. Pengaruh Implementasi UU No.22 tahun 2009 Tentang Lalu Lintas Angkutan Jalan (LLAJ) Terhadap Disiplin Pengemudi Angkutan Kota Di Kota Bogor 


\section{PENDAHULUAN}

Transportasi merupakan sarana yang sangat penting dan strategis dalam memperlancar roda perekonomian, memperkukuh persatuan dan kesatuan serta mempengaruhi semua aspek kehidupan bangsa dan negara. Transportasi memiliki posisi yang penting dan strategis dalam pembangunan bangsa yang berwawasan lingkungan dan hal ini harus tercermin pada kebutuhan mobilitas seluruh sektor dan wilayah. Kota-kota yang sustainable secara ekonomi, sosial dan lingkungan adalah visi kota yang diperkuat oleh pelayanan angkutan umum sebagai tulang punggung pergerakan mayoritas penduduk, berdaya saing dan memberikan kontribusi terhadap rendahnya biaya transportasi penduduk. Setiap alat yang digunakan sebagai acuan manajemen lalu lintas, perundang-undangan atau peraturan yang ada harus ketat untuk mendapatkan fokus dan perhatian yang lebih besar, sehingga lebih tertata dan teratur dalam pengaplikasiannya. Undang-undang Nasional, Peraturan Pemerintah, dan Peraturan Daerah hanya berarti jika kebijakannya dapat diimplementasikan dengan ditegakkannya law in forcement yang bertanggung jawab. Hal yang paling penting adalah semua pihak bertanggung jawab dalam implementasi dan penerapan dari kebijakan dan undang-undang yang telah dibuat dengan mematuhi peraturan dengan menunjukan transparansi hukum, menjaga implementasi sesuai dengan porsi kebijakan yang telah diatur, serta proses penegakannya yang tetap konsisten.

Paratransit (angkot) merupakan angkutan umum dengan karakter kendaraan kecil, kepemilikan sebagian besar oleh individu, untuk melayani rute jarak pendek yang penetapannya dilakukan oleh pemerintah kota, dengan pengawasan yang masih lemah. Tarif angkot cukup rendah, namun perawatan dan investasinya juga rendah, serta kelaikan kendaraannya sering menjadi masalah. Paratransit di negara maju tidak berkembang karena layanan angkutan umumnya sudah lebih baik dan untuk memperoleh subsidi pemerintah, harus memenuhi syarat pelayanan dan penegakan hukum yang ketat. Angkot sampai saat ini masih mendominasi pelayanan angkutan perkotaan di kota-kota Indonesia. Masalah penyelenggaraan angkot yang ada saat ini adalah besarnya beban izin yang harus ditanggung oleh pemkot (regulatory overload) yang masih memiliki kelemahan, tidak saja dari perizinan itu sendiri melainkan juga pada mutu pengawasan yang masih rendah sehingga kepemilikan individu yang banyak menjadi semakin banyaknya pungutan liar. Harapan dalam pengembangan angkot kedepan adalah menjadi angkutan terorganisir sehingga menjadi andalan angkutan umum perkotaan, melalui proses penataan dengan konsep perbaikan kebijakan yang lebih terarah, penataan struktur industri yang responsif terhadap permintaan (demand), perencanaan dan peraturan sesuai kebijakan serta peningkatan sumber daya manusia.

Jumlah angkot yang hampir mencapai 3412 unit di Kota Bogor memberikan sumbangan besar pada kemacetan lalu lintas berpengaruh terhadap situasi di jalan raya dimana jalan raya digunakan bukan hanya oleh angkot saja, melainkan pengguna angkutan umum lainnya, motor, serta mobil pribadi harus disertai kesadaran dalam mengemudi dan juga harus mentaati peraturan yang berlaku tentang tata cara berlalulintas yang baik agar tercipta situasi yang kondusif, nyaman dan aman demi keselamatan semua pengguna jalan. Demi menciptakan masyarakat yang aman dan tertib dalam berlalu lintas, pemerintah membuat suatu perundangan, yaitu dalam bentuk UndangUndang No. 22 tahun 2009 tentang Lalu Lintas Dan Angkutan Jalan.

Dengan diberlakukannya aturan ini, maka pemerintah dalam hal ini pihak terkait seperti kepolisian diberi wewenang untuk menindak pelaku pelanggaran bagi pengguna lalu lintas. Undang-Undang 
Nomor 22 Tahun 2009 tentang Lalu Lintas dan Angkutan Jalan telah ditetapkan dalam Rapat Paripurna DPR RI pada tanggal 26 Mei 2009 yang kemudian disahkan oleh Presiden RI pada tanggal 22 Juni 2009. Undang-Undang ini adalah kelanjutan dari Undang-Undang Nomor 14 Tahun 1992, terlihat bahwa kelanjutannya adalah merupakan pengembangan yang signifikan dilihat dari jumlah clausul yang diaturnya, yakni yang tadinya 16 bab dan 74 pasal, menjadi 22 bab dan 326 pasal.

Untuk melihat UU ini bisa dilaksanakan atau tidak, hal ini bisa dilihat seberapa banyak pasal yang harus diterjemahkan lagi dalam peraturan pelaksana dan teknis. Sebagai acuan dalam implementasi UU No.22 tahun 2009 tersebut Dinas terkait DLLAJ Kota Bogor dalam melaksanakan tugasnya di lapangan (jalan) khususnya berkaitan dengan Lalu Lintas Angkutan Kota di Kota Bogor memiliki dasar hukum dan aturan sebagai berikut:

Dasar Hukum Realisasi Pelaksanaan UU No.22 Tahun 2009 Yang Diterapkan DLLAJ Kota Bogor Sesuai TUPOKSInya

Pasal 6 ayat (I) sub B jo Ps. 212 UU No.8 Tahun 1981 tentang Hukum Acara Pidana.

Pasal 262 UU 22 tahun 2009 tentang LLAJ.

Pasal 3 dan Pasal 4 Perda Kota Bogor No. 12 tahun 2007 tentang PPNS.

Pasal 125 Perda Kota Bogor No.6 Tahun 2005 tentang penyelenggaraan LLAJ.

Jenis-jenis Pelanggaran

Mengakibatkan gangguan pada: Fungsi rambu lalu lintas, Marka jalan, Alat pemberi isyarat lalu lintas, Fasilitas pejalan kaki, dan alat pengaman pengguna jalan. (pasal. 275 ayat (I) jo. Pasal. 28 ayat (2).

Melanggar aturan gerakan lalu lintas atau tata cara berhenti dan parkir. (Pasal. 287 jo. Pasal. 106 ayat (4) huruf e.

Melanggar aturan perintah atau larangan yang dinyatakan dengan rambu lalu lintas. (Pasal. 287 ayat (I) jo Pasal. 107 ayat 4 huruf a dan pasal 106 ayat 4 huruf b).
Melanggar aturan perintah atau larangan yang dinyatakan dengan alat pemberi Isyarat Lalu Lintas (Pasal. 287 ayat (2) jo Pasal. 106 ayat (4) huruf c.).

Melakukan kegiatan lain saat mengemudi (Pasal.283 jo. Pasal 106 ayat (I).

Tanpa Ijin dalam Trayek. (Pasal. 308a jo Pasal. 173 ayat (I) huruf a).

Tanpa Ijin tidak dalam Trayek (Pasal. 308b jo Pasal. 173 ayat (1) huruf b).

Ijin Trayek menyimpang (Pasal. 308 huruf c jo Pasal.173).

Ngetem, menaikkan/turunkan penumpang tidak di halte, melanggar jalur trayek (Pasal. 302 jo Pasal.126).

Secara substansi, UU Nomor 22 Tahun 2009 masih dapat diperdebatkan. Mulai dari banyaknya amanat untuk membuat aturan pelaksana dan teknis, nilai keefektifan dari penegakan hukum berupa sanksi administrasi, perdata hingga pada pidana, pengaturan mengenai hak dan kewajiban dari penyelenggara negara dan masyarakat, dan sebagainya. Pertanyaanpertanyaan ini adalah untuk lebih mendalami apakah peraturan ini dapat dilaksanakan, kedayagunaan dan kehasilgunaan. Selain itu, apakah norma peraturan tersebut memang lahir dari masyarakat, hal ini guna menjawab kebutuhan siapa yang memang harus dipenuhi. Dengan memperhatikan ini, maka kita dapat melihat apakah suatu peraturan ini akan efektif dan efisien jika dilaksanakan.

Dengan berlakunya UU No. 22 Tahun 2009 tersebut diharapkan dapat membantu mewujudkan kepastian hukum bagi pihak-pihak yang terkait dengan penyelenggaraan jasa angkutan, baik itu pengusaha angkutan, pekerja (sopir/ pengemudi) serta penumpang. Semua itu dilakukan sebagai bagian dari kedisiplinan pengemudi/supir angkutan umum tersebut. Beberapa realita tentang pelanggaran yang terjadi adalah sebagai berikut: 
1. Dalam kenyataannya di Kota Bogor masih sering pengemudi angkutan melakukan tindakan yang dinilai dapat menimbulkan kerugian bagi penumpang, baik itu kerugian yang secara nyata dialami oleh penumpang (kerugian materiil), maupun kerugian yang secara immateriil seperti kekecewaan dan ketidaknyamanan yang dirasakan oleh penumpang. Kota Bogor saat ini berkembang dengan pesat, perkembangan tersebut akan memicu timbulnya dampak pada sektor transportasi salah satunya yaitu pada sektor angkutan umum. Masih banyaknya oknum pengemudi yang berhenti menurunkan/menaikkan penumpang tidak pada tempatnya, sehingga menimbulkan kemacetan. Parkir liar/ ngetem sembarangan serta tidak mematuhi rambu-rambu larangan, seperti rambu dilarang parkir dan rambu dilarang berhenti. Dalam hal pengemudi, masih banyak ditemukan pengemudi abal-abal (supir tembak) dan juga supir dibawah umur yang dapat membahayakan penumpang. Dalam hal pelanggaran ini, DLLAJ Kota Bogor menindak tegas segala bentuk pelanggaran sesuai hukum yang berlaku beserta tindakan, peringatan serta himbauan sesuai dengan tupoksi DLLAJ Kota Bogor.

2. Sering kali terlihat kecelakaan terjadi di Kota Bogor, dan ini sering terjadi pada angkutan umum yang tidak mematuhi peraturan lalu lintas sehingga menimbulkan kerugian pada penumpang ataupun kendaraan lainnya, dikarenakan para supir semena-mena dalam mengendarai kendaraan yang digunakannya. Misalnya saja tindakan pengemudi yang mengemudi secara tidak wajar dalam arti saat menjalani tugasnya pengemudi dipengaruhi oleh keadaan sakit, lelah, meminum sesuatu yang dapat mempengaruhi kemampuannya, mengemudikan kendaraan secara ugalugalan sehingga menyebabkan terjadinya kecelakaan dan penumpang yang menjadi korban. Menurut UU Nomor 22 tahun 2009 diatur bahwa perusahaan angkutan umum wajib memenuhi standar pelayanan minimal, memenuhi bagi penggunanya berupa keamanan, keselamatan, kenyamanan, keterjangkauan, kesetaraan, keteraturan dan mengakomodir kebutuhan penyandang cacat. Hal ini tentu saja melanggar pasal 23 ayat 1 (a) UULLAJ "Penyelenggara Jalan dalam melaksanakan preservasi jalan dan/atau peningkatan kapasitas jalan wajib menjaga Keamanan, Keselamatan, Ketertiban, dan Kelancaran Lalu Lintas dan Angkutan Jalan".

3. Tindakan lainnya adalah pengemudi melakukan penarikan tarif yang tidak sesuai dengan tarif resmi seperti menarik biaya angkutan lebih dari tarif resmi. Atau tindakan lain seperti menurunkan di sembarang tempat yang dikehendaki tanpa suatu alasan yang jelas, sehingga tujuan pengangkutan yang sebenarnya diinginkan oleh penumpang tidak terlaksana. Hal ini tentu saja melanggar ketentuan pasal 45 (1) UULLAJ mengenai tanggung jawab pengangkut terhadap penumpang yang dimulai sejak diangkutnya penumpang sampai di tempat tujuan. Dan adanya perilaku pengangkut yang mengangkut penumpang melebihi kapasitas maksimum kendaraan.

\section{MATERI DAN METODE}

Metode Penelitian yang digunakan adalah Penelitian Asosiatif. Metode penelitian tersebut menjelaskan penelitian yang dilakukan pada populasi besar maupun kecil. Penelitian Asosiatif merupakan penelitian yang bertujuan untuk mengetahui hubungan antara dua variabel atau lebih. Dengan penelitian ini maka akan dapat dibangun suatu teori yang dapat berfungsi untuk menjelaskan, meramalkan, dan mengontrol suatu gejala. (Sugiyono, 2011:11).

\section{Teknik Penarikan sampel}

Menurut Djarwanto (2007:10) Sebelum menguraikan, mengemukakan, menjelaskan atau memberikan pernyataan 
tentang suatu persoalan maka terlebih dahulu mengadakan penelitian mengenai persoalan yang akan disajikan. Dengan demikian pernyataan yang kita buat cukup beralasan dan dapat dipertanggung jawabkan. Persoalan dengan batasbatasnya yang sudah cukup jelas diketahui, yang akan dibuat pernyataan berdasarkan penelitian disebut populasi atau universum. Jadi dengan demikian yang disebut populasi adalah objek penelitian dengan batas-batas persoalan yang sudah cukup jelas. Dalam hal ini yang menjadi populasi adalah karyawan DLLAJ di Kota Bogor sebanyak 70 orang yang berasal dari beberapa bidang ahli yang dianggap sesuai dengan ruang lingkup penelitian serta supir angkutan kota di Kota Bogor sebanyak 3412 orang (Sumber: Subsi Angkutan Orang DLLAJ Kota Bogor 2012).

Rumus dalam menentukan jumlah sampel pegawai DLLAJ Kota Bogor dan pengemudi angkutan kota di Kota Bogor dengan menggunakan rumus Yamane menurut Ridwan dan Akdon (2009:249) yaitu:

\section{Keterangan:}

$$
\begin{aligned}
\mathrm{N} & =\text { Populasi } \\
\mathrm{n} & =\text { Ukuran Sampel } \\
\mathrm{d}^{2} & =\text { Presisi }(\operatorname{taraf} 0,1) \\
n & =\frac{N}{N d^{2}+1}=\frac{70}{70 \cdot(0,1)^{2}+1}=\frac{70}{70.0,01+1}= \\
\frac{70}{1,7} & ==41,17=41 \text { orang. }
\end{aligned}
$$

Jumlah tersebut sesuai dengan perhitungan masing-masing anggota sampel yaitu: $n=\frac{N i}{N} x n$

1. Pimpinan Dinas : $\frac{1}{70} \times 41=0,58=$ 1 orang

2. Ka.Sie $: \frac{3}{70} \times 41=1,76=$

2 orang

3. Bid. Lalin $\quad: \frac{4}{70} x 41=2,34=$

2 orang

4. Bid. Kestib $: \frac{4}{70} \times 41=2,34=$ 2 orang
5.Bid. Angkutan: $\quad \frac{18}{70} \times 41=10,54=$ 11 orang

6. Bid. Daltib : $\frac{40}{70} x 41=23,43=23$ orang. Total sampel pegawai DLLAJ Kota Bogor berjumlah 41 orang.

Untuk jumlah sampel yang diambil dari pengemudi angkutan kota di Kota Bogor dari populasi sebanyak 3412 orang dengan perhitungan sebagai berikut:

$n=\frac{N}{N d^{2}+1}=\frac{3412}{3412 \cdot(0,1)^{2}+1}=\frac{3412}{3412 \cdot 0,01+1}=$ $\frac{3412}{35,12}=97,15=97$ pengemudi.

\section{Jenis dan Teknik Pengumpulan Data}

Pengumpulan data yang dilakukan oleh penulis untuk dapat melengkapi penyusunan skripsi ini melalui beberapa jenis prosedur atau teknik pengumpulan data, yaitu :

1. Studi Lapangan, antara lain yaitu :

Wawancara, yaitu proses interaksi dan komunikasi untuk memperoleh data yang diperlukan. Dalam hal ini penulis melakukan wawancara dengan pihak-pihak yang berhubungan langsung dengan permasalahan yang akan diteliti.

a. Observasi Partisipan, yaitu pengamatan langsung data-data yang berhubungan mengenai variabel yang akan diteliti melalui pengajuan permohonan pengambilan data ke instansi terkait, observasi tentang masalah yang akan dibahas sesuai dengan judul yang dibuat oleh peneliti.

b. Kuesioner

Kuesioner meliputi pertanyaanpertanyaan yang akan diberikan oleh penulis kepada responden dimana didalam kuesioner tersebut berisi point-point pertanyaan yang berhubungan dengan judul skripsi yang ditulis oleh penulis, yang hasilnya akan dijadikan bahan data untuk kemudian diolah.

c. Studi Pustaka

Yaitu penelitian yang dilakukan dengan cara membaca dan mempelajari 
teori-teori dari beberapa ahli dalam materi yang akan dibahas melalui buku-buku, litelatur, majalah dan sebagainya yang menurut penulis dapat mendukung isi serta berhubungan dengan judul skripsi yang dibuat oleh penulis.

\section{Teknik Analisa Data}

Analisa data untuk mengukur hubungan variabel Implementasi dan variabel Disiplin dihitung dengan menggunakan Weight Mean Score (WMS). Lalu teknik analisis yang digunakan dalam penelitian adalah menggunakan skala pengukuran instrumen yaitu skala Likert dimana pengaruh implementasi serta penilaian tentang tingkat disiplin pengemudi angkot dinilai melalui pendapat serta pernyataan instansi terkait serta para pengguna jasa layanan angkutan kota tersebut sebagai responden.

Skala Likert mempunyai skor terhadap sikap atau persepsi responden seperti:

-Sangat Baik/Sangat Menguasai/Sangat Mampu/Sangat Mudah/Sangat Paham = (SB) diberi skor $=5$

-Baik / Menguasai / Mampu / Mudah / Paham $=($ B ) diberi skor $=4$

-Cukup baik/Cukup Menguasai/Cukup Mampu/Cukup Mudah/Cukup Paham = (CB) diberi skor $=3$

-Kurang Baik/Kurang Menguasai/Kurang Mampu/Kurang Paham $=(\mathrm{KB})$ diberi skor $=2$

-Sangat Kurang Baik/ Tidak Menguasai/ Tidak Mampu/ Tidak Paham =(SKB) diberi skor $=1$

Kemudian rumus Weight Mean Score yang digunakan yaitu WMS $=\frac{\sum f(x)}{n}$ dengan kriteria sebagai berikut:

Kriteria = Interval

\section{HASIL DAN PEMBAHASAN}

Adapun hasil penelitian tentang Implementasi UU No.22 Tahun 2009 tentang LLAJ berdasarkan ukuran tiap dimensi dapat dilihat dalam penjelasan berikut ini:

Tabel 5.
Nilai skor tertinggi $=5$

Nilai skor terendah $=1$

Dengan perhitungan interval nilai : $\frac{5-1}{5}=$ 0,8

Berikut adalah kriteria analisis data dengan menggunakan Weight Mean Score yaitu sebagai berikut:

1. $1-1,8=$ Sangat Kurang

2. $1,8-2,6=$ Kurang

3. $2,6-3,4=$ Cukup

4. $3,4-4,2=$ Baik

5. $4,2-5=$ Sangat Baik

Kemudian dengan teknik pengumpulan data angket, maka kuesioner yang telah dibuat akan disebar kepada 41 responden karyawan DLLAJ Kota Bogor dan 97 sopir angkutan kota di Kota Bogor yang terpilih sebagai sampel yang hasil penyebaran angket tersebut akan berupa jawaban serta skornya nanti akan menjadi data yang diolah.

Untuk menguji ada tidaknya pengaruh variabel kinerja terhadap variabel kualitas pelayanan digunakan rumus Korelasi Rank Spearman.

$$
r_{s}=1-\frac{6 \sum D^{2}}{n\left(n^{2}-1\right)}
$$

Kriteria keeratan hubungan dengan menggunakan koefisien korelasi yaitu sebagai berikut:

1. $0,00-0,19=$ hubungan sangat lemah

2. $0,20-0,39=$ hubungan lemah

3. $0,40-0,59=$ hubungan cukup kuat

4. $0,60-0,79=$ hubungan kuat

5. $0,80-1,00=$ hubungan sangat kuat

Berdasarkan data tersebut maka pengolahan data akan dilakukan dengan uji signifikasi serta koefisien determinasi menggunakan bantuan software SPSS 20.0.

Rekapitulasi rata-rata skor variabel Implementasi untuk dimensi standard dan tujuan pelaksanaan

\begin{tabular}{|c|l|c|}
\hline No & \multicolumn{1}{|c|}{ Indikator } & $\begin{array}{c}\text { Rata-rata } \\
\text { skor }\end{array}$ \\
\hline 1 & $\begin{array}{l}\text { Memahami Maksud } \\
\text { Serta Tujuan } \\
\text { Pelaksanaan }\end{array}$ & 3,60 \\
\hline 2 & Mengerti Standar & 3,32 \\
\hline
\end{tabular}




\begin{tabular}{|l|l|c|} 
& $\begin{array}{l}\text { Keberhasilan } \\
\text { Pelaksanaan }\end{array}$ & \\
\hline & Rata-rata skor & 3,46 \\
\hline
\end{tabular}

Berdasarkan tabel diketahui ratarata skor untuk dimensi standard dan tujuan pelaksanaan adalah sebesar 3,46 dengan interpretasi Baik.

Tabel 8.

Rekapitulasi rata-rata skor variabel Implementasi untuk dimensi sumber daya sarana dan prasarana

\begin{tabular}{|c|l|c|}
\hline No & \multicolumn{1}{|c|}{ Indikator } & $\begin{array}{c}\text { Rata-rata } \\
\text { skor }\end{array}$ \\
\hline 1 & $\begin{array}{l}\text { Adanya Media, } \\
\text { Peralatan Pendukung } \\
\text { Kegiatan }\end{array}$ & 3,31 \\
\hline 2 & $\begin{array}{l}\text { Adanya SDM Yang } \\
\text { Memadai }\end{array}$ & 3,09 \\
\hline & Rata-rata skor & 3,2 \\
\hline
\end{tabular}

Berdasarkan tabel di atas diketahui rata-rata skor untuk dimensi sumber daya sarana dan prasarana adalah sebesar 3,2 dengan interpretasi Cukup Baik

Tabel 11.

Rekapitulasi rata-rata skor variabel Implementasi untuk dimensi karakteristik badan pelaksana

\begin{tabular}{|c|l|c|}
\hline No & \multicolumn{1}{|c|}{ Indikator } & $\begin{array}{c}\text { Rata-rata } \\
\text { skor }\end{array}$ \\
\hline 1 & $\begin{array}{l}\text { Aturan dan kebijakan } \\
\text { pelaksana }\end{array}$ & 3,24 \\
\hline 2 & $\begin{array}{l}\text { Efektifitas badan } \\
\text { pelaksana kebijakan }\end{array}$ & 3,28 \\
\hline & Rata-rata skor & 3,26 \\
\hline
\end{tabular}

Berdasarkan tabel di atas diketahui rata-rata skor untuk dimensi karakteristik badan pelaksana adalah sebesar 3,26 dengan interpretasi Cukup Baik.

Tabel 14.

Rekapitulasi rata-rata skor variabel Implementasi untuk dimensi kondisi sosial, ekonomi dan politik

\begin{tabular}{|c|l|c|}
\hline No & \multicolumn{1}{|c|}{ Indikator } & $\begin{array}{c}\text { Rata-rata } \\
\text { skor }\end{array}$ \\
\hline 1 & $\begin{array}{l}\text { Faktor situasi dan } \\
\text { kondisi lingkungan }\end{array}$ & 3,40 \\
\hline 2 & $\begin{array}{l}\text { Pengaruh kebijakan } \\
\text { yang sedang terlaksana }\end{array}$ & 3,23 \\
\hline & Rata-rata skor & 3,32 \\
\hline
\end{tabular}

Berdasarkan tabel diketahui ratarata skor untuk dimensi kondisi sosial, ekonomi dan politik adalah sebesar 3,32 dengan interpretasi Cukup Baik.

Tabel 15.

Rekapitulasi rata-rata skor keseluruhan dimensi pada variabel Implementasi

\begin{tabular}{|c|l|c|}
\hline No & \multicolumn{1}{|c|}{ Dimensi } & $\begin{array}{c}\text { Rata-rata } \\
\text { skor }\end{array}$ \\
\hline 1 & $\begin{array}{l}\text { Standar dan tujuan } \\
\text { pelaksanaan }\end{array}$ & 3,46 \\
\hline 2 & $\begin{array}{l}\text { Sumber daya sarana dan } \\
\text { prasarana }\end{array}$ & 3,20 \\
\hline 3 & $\begin{array}{l}\text { Karakteristik badan } \\
\text { pelaksana }\end{array}$ & 3,26 \\
\hline 4 & $\begin{array}{l}\text { Kondisi sosial, ekonomi } \\
\text { dan politik }\end{array}$ & 3,32 \\
\hline & Rata-rata skor & 3,31 \\
\hline
\end{tabular}

Berdasarkan tabel di atas diketahui rata-rata skor akhir keseluruhan dimensi pada variabel Implementasi adalah sebesar 3,31 dengan interpretasi Cukup Baik.

Adapun hasil penelitian tentang Disiplin mengemudi berdasarkan ukuran tiap dimensi dapat dilihat dalam penjelasan berikut ini:

Tabel 18.

Rekapitulasi rata-rata skor variabel disiplin kerja untuk dimensi mematuhi semua

peraturan

\begin{tabular}{|c|l|c|}
\hline No & \multicolumn{1}{|c|}{ Indikator } & $\begin{array}{c}\text { Rata-rata } \\
\text { skor }\end{array}$ \\
\hline 1 & $\begin{array}{l}\text { Kemampuan menjalankan } \\
\text { kewajiban/tugas }\end{array}$ & 3,24 \\
\hline 2 & $\begin{array}{l}\text { Kepatuhan mentaati } \\
\text { aturan yang berlaku }\end{array}$ & 3,31 \\
\hline & Rata-rata skor & 3,28 \\
\hline
\end{tabular}


Berdasarkan tabel di atas diketahui rata-rata skor untuk dimensi mematuhi semua peraturan adalah sebesar 3,28 dengan interpretasi Cukup Baik.

Tabel 21.

Rekapitulasi rata-rata skor variabel disiplin untuk dimensi penggunaan waktu secara efektif

\begin{tabular}{|c|l|c|}
\hline No & \multicolumn{1}{|c|}{ Indikator } & $\begin{array}{c}\text { Rata- } \\
\text { rata } \\
\text { skor }\end{array}$ \\
\hline 1 & Ketepatan waktu pelayanan & 3,27 \\
\hline 2 & Kemampuan manajemen waktu & 3,30 \\
\hline & Rata-rata skor & 3,29 \\
\hline
\end{tabular}

Berdasarkan tabel diketahui rata-rata skor untuk dimensi penggunaan waktu secara efektif adalah sebesar 3,29 dengan interpretasi Cukup Baik.

Tabel 24.

Rekapitulasi rata-rata skor variabel Disiplin untuk dimensi tanggungjawab dalam pekerjaan

\begin{tabular}{|c|l|c|}
\hline No & \multicolumn{1}{|c|}{ Indikator } & $\begin{array}{c}\text { Rata- } \\
\text { rata } \\
\text { skor }\end{array}$ \\
\hline 1 & $\begin{array}{l}\text { Kepedulian dan perhatian } \\
\text { terhadap tugas }\end{array}$ & 3,41 \\
\hline 2 & Konsistensi pada pekerjaan & 3,30 \\
\hline & Rata-rata skor & 3,36 \\
\hline
\end{tabular}

Berdasarkan tabel diketahui ratarata skor untuk dimensi tanggungjawab dalam pekerjaan adalah sebesar 3,36 dengan interpretasi Cukup Baik

Tabel 27.

Rekapitulasi rata-rata skor variabel Disiplin untuk dimensi tingkat absensi

\begin{tabular}{|c|l|c|}
\hline No & \multicolumn{1}{|c|}{ Indikator } & $\begin{array}{c}\text { Rata- } \\
\text { rata } \\
\text { skor }\end{array}$ \\
\hline 1 & $\begin{array}{l}\text { Tingkat kehadiran sesuai } \\
\text { jadwal }\end{array}$ & 3,40 \\
\hline 2 & Pegawai datang tepat waktu & 3,25 \\
\hline & Rata-rata skor & 3,33 \\
\hline
\end{tabular}

Berdasarkan tabel diketahui ratarata skor untuk dimensi tanggungjawab dalam pekerjaan adalah sebesar 3,33 dengan interpretasi Cukup Baik, hanya belum optimal.

Tabel 28.

Rekapitulasi rata-rata skor keseluruhan dimensi pada variabel disiplin

\begin{tabular}{|c|l|c|}
\hline No & \multicolumn{1}{|c|}{ Dimensi } & $\begin{array}{c}\text { Rata-rata } \\
\text { skor }\end{array}$ \\
\hline 1 & $\begin{array}{l}\text { Mematuhi semua } \\
\text { peraturan }\end{array}$ & 3,28 \\
\hline 2 & $\begin{array}{l}\text { Penggunaan waktu } \\
\text { secara efektif }\end{array}$ & 3,29 \\
\hline 3 & $\begin{array}{l}\text { Tanggungjawab dalam } \\
\text { pekerjaan }\end{array}$ & 3,36 \\
\hline 4 & Tingkat absensi & 3,33 \\
\hline \multicolumn{2}{|l|}{ Rata-rata skor } & 3,31 \\
\hline
\end{tabular}

Berdasarkan tabel di atas diketahui rata-rata skor akhir keseluruhan dimensi pada variabel disiplin adalah sebesar 3,31 dengan interpretasi Cukup Baik, hanya belum optimal.

Tabel 29.

Hasil Uji SPSS Hubungan Korelasi antara Implementasi dengan Disiplin Kerja Nonparametric Correlations

\begin{tabular}{|c|c|c|c|c|}
\hline \multicolumn{5}{|c|}{ Correlations } \\
\hline & & & $\begin{array}{c}\text { Imple } \\
\text { menta } \\
\text { si }\end{array}$ & $\begin{array}{l}\text { Disipl } \\
\text { in } \\
\text { Kerja }\end{array}$ \\
\hline \multirow{6}{*}{$\begin{array}{l}\text { Spe } \\
\text { arm } \\
\text { an's } \\
\text { rho }\end{array}$} & \multirow{3}{*}{$\begin{array}{l}\text { Im } \\
\text { ple } \\
\text { me } \\
\text { nta } \\
\text { si }\end{array}$} & $\begin{array}{c}\text { Correlatio } \\
\mathrm{n} \\
\text { Coefficien } \\
\mathrm{t}\end{array}$ & 1.000 & $.919^{* *}$ \\
\hline & & $\begin{array}{l}\text { Sig. (2- } \\
\text { tailed) }\end{array}$ & . & .000 \\
\hline & & $\mathrm{N}$ & 138 & 138 \\
\hline & \multirow[t]{3}{*}{$\begin{array}{l}\text { Disi } \\
\text { plin } \\
\text { Kerj } \\
\text { a }\end{array}$} & $\begin{array}{c}\text { Correlatio } \\
n \\
\text { Coefficien } \\
t \\
\end{array}$ & $.919^{* *}$ & 1.000 \\
\hline & & $\begin{array}{l}\text { Sig. (2- } \\
\text { tailed) }\end{array}$ & .000 & . \\
\hline & & $\mathrm{N}$ & 138 & 138 \\
\hline \multicolumn{5}{|c|}{$\begin{array}{l}\text { **. Correlation is significant at the } 0.01 \text { level } \\
\text { (2-tailed). }\end{array}$} \\
\hline
\end{tabular}


Sumber : Hasil data diolah (2015)

Dari analisis korelasi spearman's didapat koefisien korelasi yang digunakan untuk mengetahui keeratan hubungan dan arah hubungan, sedangkan signifikasi untuk mengetahui apakah hubungan yang terjadi berarti atau tidak. Untuk mengetahui keeratan hubungan maka dapat dilihat pada besarnya koefisien korelasi dengan pedoman yaitu jika koefisien semakin mendekati 1 atau -1 maka hubungan erat atau kuat, sedangkan jika koefisien semakin mendekati "0" maka hubungan lemah. Kesimpulannya dari hasil out put diatas, dilihat dari masing-masing Item dengan Label A (sebagai Variabel Implementasi) dan Label B (sebagai Variabel Disiplin Kerja) dapat diperhatikan untuk koefisien korelasi masing-masing item semakin mendekati "1" maka hubungan korelasi antara Implementasi dan Disiplin Kerja memiliki hubungan yang erat dan kuat. Dengan tanda positif, maka hubungan pun kearah yang positif, dengan demikian artinya jika Implementasi UU No.22 Tahun 2009 tersebut dipahami dengan baik, maka berpengaruh pada Disiplin Kerja pengemudi angkot yang baik pula, demikian sebaliknya pula apabila Implementasi UU No.22 tahun 2009 tersebut kurang dipahami, maka akan berpengaruh pada menurunnya nilai Disiplin Kerja pengemudi angkot tersebut.

Tabel 30.

Interpretasi Rank Variabel X danY Created Variables ${ }^{a}$

\begin{tabular}{|l|l|l|l|}
\hline $\begin{array}{l}\text { Source } \\
\text { Variable }\end{array}$ & Funtion & $\begin{array}{l}\text { New } \\
\text { Vari } \\
\text { able }\end{array}$ & Label \\
\hline $\mathrm{X}^{\mathrm{b}}$ & $\begin{array}{l}\text { Normal } \\
\text { Score }\end{array}$ & NX & $\begin{array}{l}\text { Normal Score } \\
\text { Of X using } \\
\text { Blom's } \\
\text { Formula by Y } \\
\text { Rank of X by Y }\end{array}$ \\
\hline
\end{tabular}

a. Mean rank of tied values is used for ties.

b. Ranks are in ascending order.
Tabel 31.

Tabel SPSS Perhitungan Korelasi Antara Implementasi Terhadap Disiplin Kerja

\begin{tabular}{|c|c|c|c|c|c|}
\hline \multicolumn{6}{|c|}{ Correlations } \\
\hline \multirow[t]{10}{*}{$\begin{array}{l}\text { Spear } \\
\text { man's } \\
\text { rho }\end{array}$} & & & $\mathrm{X}$ & $\mathrm{Y}$ & $\begin{array}{l}\text { Rank } \\
\text { of X by } \\
Y\end{array}$ \\
\hline & \multirow[t]{3}{*}{$\mathrm{X}$} & $\begin{array}{l}\text { Corre } \\
\text { lation } \\
\text { Coeffi } \\
\text { cient }\end{array}$ & 1.000 & $.919^{* *}$ & $.680^{* *}$ \\
\hline & & $\begin{array}{l}\text { Sig. } \\
(2- \\
\text { tailed } \\
)\end{array}$ & $\cdot$ & .000 & .000 \\
\hline & & $\mathrm{N}$ & 138 & 138 & 138 \\
\hline & \multirow[t]{3}{*}{$\mathrm{Y}$} & $\begin{array}{l}\text { Corre } \\
\text { lation } \\
\text { Coeffi } \\
\text { cient }\end{array}$ & $.919^{* *}$ & 1.000 & $.919^{*}$ \\
\hline & & $\begin{array}{l}\text { Sig. } \\
(2- \\
\text { tailed } \\
\text { ) }\end{array}$ & .000 & · & .052 \\
\hline & & $\mathrm{N}$ & 138 & 138 & 138 \\
\hline & \multirow[t]{3}{*}{$\begin{array}{l}\text { Rank } \\
\text { of X } \\
\text { by Y }\end{array}$} & $\begin{array}{l}\text { Cor } \\
\text { rela } \\
\text { tion } \\
\text { Coe } \\
\text { ffici } \\
\text { ent } \\
\end{array}$ & $.680^{* *}$ & $.919^{*}$ & 1.000 \\
\hline & & $\begin{array}{l}\text { Sig. } \\
\text { (2- } \\
\text { taile } \\
\text { d) }\end{array}$ & .000 & .052 & . \\
\hline & & $\mathrm{N}$ & 138 & 138 & 138 \\
\hline $\begin{array}{l}* * \text {. Cor } \\
\text { tailed) }\end{array}$ & tion $\mathrm{i}$ & gnific & $t$ at th & 01 leve & \\
\hline
\end{tabular}

Sumber : Hasil data diolah (2015)

Dari data output di atas didapat koefisien korelasi Spearman's rho sebesar 0,919. Karena nilai lebih mendekati 1 maka hubungan antara Implementasi dengan Disiplin Kerja adalah kuat. Nilai pada Rank pun tinggi dan positif yaitu sebesar 0,680. Nilai koefisien bertanda positif (+), artinya jika Item Implementasi tinggi maka Item Disiplin Kerja akan mengalami peningkatan tinggi atau jika Item Implementasi rendah maka akan berpengaruh pada Disiplin Kerja yang rendah juga. Lalu untuk mengetahui hubungan berarti atau tidak 
dilakukan pengujian signifikasi dengan langkah-langkah sebagi berikut:

a. Penentuan Hipotesis nol dan Hipotesis Alternatif

Ho: Artinya tidak ada hubungan antara Implementasi dengan Disiplin Kerja

Ha: Artinya ada hubungan antara Implementasi dengan Disiplin Kerja

Dari hasil output diatas dapat diketahui taraf signifikansi sebesar 0,000

b. Pengambilan Keputusan

Signifikansi $>0,05$ jadi Ho diterima

Signifikansi $\leq 0,05$ jadi Ho ditolak

Dapat diketahui bahwa signifikansi sebesar 0,000 kurang dari 0,05 maka hipotesis nol ditolak, kesimpulannya yaitu ada hubungan yang erat dan berarti antara penerapan Implementasi UU No.22 tahun 2009 terhadap Disiplin Kerja Sopir Angkot di Kota Bogor.

\section{KESIMPULAN DAN IMPLIKASI}

Berdasarkan hasil penelitian yang dilakukan oleh penulis yaitu penelitian tentang Pengaruh Implementasi UU No.22 Tahun 2009 Tentang Lalu Lintas Angkutan Jalan (LLAJ) Terhadap Disiplin Pengemudi Angkutan Kota Di Kota Bogor, maka hasil penelitian yang diolah untuk mengetahui hasil dari kuesioner yang disebarkan pada 138 orang responden dengan 16 pertanyaan dan terdiri dari 2 variabel pertanyaan yaitu variabel Implementasi dan variabel Disiplin Kerja didapatkan kesimpulan sebagai berikut:

1. Pengaruh Implementasi UU No.22 Tahun 2009 Tentang LLAJ Terhadap Disiplin Pengemudi Angkutan Kota di Kota Bogor adalah cukup baik dengan rata-rata skor 3,31. Faktor yang paling tinggi nilainya adalah pada dimensi Standard dan Tujuan Pelaksanaan dengan rata-rata skor sebesar 3,46. Sedangkan paling rendah ada pada dimensi Sumber Daya Sarana dan Prasarana dengan rata-rata skor 3,20. Hal tersebut menunjukkan bahwa
Implementasi UU No.22 Tentang LLAJ di Kota Bogor dengan ini menunjukkan kriteria Cukup Baik.

2. Disiplin Kerja pengemudi angkutan kota (angkot) di Kota Bogor adalah Cukup Baik dengan rata-rata skor 3,31. Faktor yang paling tinggi nilainya adalah pada dimensi Tanggungjawab Dalam Pekerjaan dengan rata-rata skor sebesar 3,36. Sedangkan paling rendah ada pada dimensi Mematuhi Semua Aturan dengan rata-rata skor 3,28. Secara keseluruhan hasil dari rekapitulasi hasil penelitian tentang disiplin kerja pengemudi angkutan kota di Kota Bogor menunjukkan Cukup Baik.

3. Berdasarkan hasil analisis menggunakan software SPSS Versi 20.0 yang diolah untuk mengetahui Korelasi Hubungan Pengaruh serta Signifikansi antara Variabel Implementasi terhadap Disiplin Kerja maka didapatkan hasil olahan data SPSS sebagai berikut :

a. Dapat diketahui bahwa signifikansi sebesar 0,000 kurang dari 0,05 maka hipotesis nol ditolak, kesimpulannya yaitu ada hubungan yang erat dan berarti antara penerapan Implementasi UU No.22 tahun 2009 terhadap Disiplin Kerja Sopir Angkot di Kota Bogor.

b. Dari data output di atas didapat koefisien korelasi Spearman's rho sebesar 0,919. Karena nilai lebih mendekati 1 maka hubungan antara Implementasi dengan Disiplin Kerja adalah kuat. Nilai pada Rank pun tinggi dan positif yaitu sebesar 0,680. Nilai koefisien bertanda positif (+), artinya jika Item Implementasi tinggi maka Item Disiplin Kerja akan mengalami peningkatan tinggi atau jika Item Implementasi rendah maka akan berpengaruh pada Disiplin Kerja yang rendah juga.

c. Hubungan antara Implementasi dengan Disiplin Kerja berpengaruh secara signifikan ( kuat). 


\section{DAFTAR PUSTAKA}

AA.Anwar Prabu Mangkunegara. (2000) Manajemen Sumber Daya Manusia. PT Remaja Rosdakarya, Bandung

AA. Anwar Prabu Mangkunegara. (2011) Manajemen Sumber Daya Manusia. PT Remaja Rosdakarya, Bandung Abdurrahmat Fathoni. (2006) Manajemen Sumber Daya Manusia. Rineka, Bandung A.G. Subarsono. (2008) Analisis Kebijakan Publik. Pustaka Pelajar, Yogyakarta

Agustino, Leo. (2006) Dasar-Dasar Kebijakan Publik. CV. Alfabeta, Bandung Djarwanto. (2007) Statistik Sosial Ekonomi. BPFE, Yogyakarta

Duwi Priyatno. (2013) Analisis Korelasi, Regresi, dan Multivariate Dengan SPSS. Gava Media, Yogyakarta

Gerungan. ( 2004) Psikologi Sosial. Refika Aditama, Bandung

Hasibuan, Malayu. (2000) Manajemen, Dasar, Pengertian dan Masalah. CV Haji Masagung, Jakarta

Hasibuan, Malayu. (2008) Manajemen Sumber Daya Manusia. PT Bumi Aksara, Jakarta

Ismail Mohamad. (2007) Manajemen Operasional. PT Remaja Rosdakarya, Bandung

Kepmenhub No. 15 tahun 1997 Tentang Sistem Transportasi Nasional

Lester,James p., dan Joseph Stewart Jr., (2000) public Policy: an Evolutionary Approach. Belmont, Wadsworth
Mazmanian, Daniel H., dan Paul A. Sabatier. (2004) Implementation and Public Policy, Harper Collins, New York

Ridwan dan Akdon. (2009) Metode dan Teknik Menyusun Proposal Penelitian. Alfabeta, Bandung

Ryan Nugroho. (2003) Kebijakan Publik, formulasi, Implementasi dan Evaluasi. Elex Media Komputindo, Jakarta

Subsi Angkutan Orang DLLAJ Kota Bogor 2012

Sugiyono. (2011) Metode Penelitian Administrasi. Alfabeta, Bandung

Veithzal Rivai. (2011) Manajemen Sumber Daya Manusia Untuk Perusahaan Dari Teori Ke Praktek. PT. RAJAGRAFINDO PERSADA, Jakarta

Wahab, Solichin Abdul. (2004) Analisis Kebijakan Dari Formulasi ke Implementasi Kebijakan Negara. PT Bumi Aksara, Jakarta

Wahab, Solichin Abdul. (2008). Analisis Kebijakan Dari Formulasi ke Implementasi Kebijakan Negara. Edisi Kedua. PT Bumi Aksara, Jakarta

Widi Widodo. (2010) Moralitas, Budaya dan Kepatuhan Pajak. Alfabeta, Bandung

Widodo, Joko. (2011) Analisis Kebijakan Publik. Bayumedia Publishing, Malang

UU No.22 Tahun 2009 Tentang Lalu Lintas dan Angkutan Jalan 